\title{
Effect of shelf-life extension of birch sap using high pressure processing
}

\author{
Kyung Hwa Choi, Sun Im Kim, Dong Uk lee, Jung Tae Jeon* \\ R\&D Center, Wooyang Frozen Food Co., Ltd., Cheongyang 33315, Korea
}

\section{초고압 기술이 자작나무 수액의 저장성 향상에 미치는 영향}

\author{
최경화·김순임 · 이동욱 · 전정태* \\ (주) 우양냉동식품 중앙연구소
}

\begin{abstract}
Effects of high pressure processing on physicochemical and microorganisms properties in birch sap were investigated using variable high pressure processing conditions. The viable cell counts of untreated birch sap was $4.0 \log \mathrm{CFU}$, whereas high pressure processed sap were not detected. In birch sap was treated with 450 to $550 \mathrm{MPa}$, microorganisms were not detected during storage period, and physicochemical properties as well as color were slightly changed. The more processing time and pressure, its quality variations were more stable and then its optimum processing condition was determined with 120 sec at $550 \mathrm{MPa}$. The microorganisms and physicochemical properties of treated birch sap were investigated during storage at $5^{\circ} \mathrm{C}$ and $10^{\circ} \mathrm{C}$ for 45 and 28 days. Changes of physicochemical properties of treated birch sap were smaller than those of the untreated, but viable cell count were not detected during storage period. As for $\mathrm{pH}$, ${ }^{\circ}$ Brix, and turbidity result of birch sap, quality shelf life of control and treatment were $\mathbf{4}$ and 24 days, respectively. Especially, $\Delta E$ value of instrumental color was untreated birch sap 4 days similar with the high pressure processed it for $\mathbf{2 8}$ days. These results indicated that the high pressure processing can be used as an effective method to improve the shelf life of birch sap.
\end{abstract}

Key words : high pressure processing, birch sap, physicochemical, microorganisms, shelf-life

\section{서 론}

수액은 수목의 도관이나 사부를 통해 유동하는 액체로서 우리나라를 비롯한 여러 나라에서 음용하고 있으며(1), 우 리나라에서 음용되고 있는 대표적인 수종은 단풍나무과의 고로쇠나무와 당단풍나무, 자작나무과의 자작나무, 박달나 무, 물박달나무, 거제수나무, 사스래나무 등으로 대별할 수 있다(2,3). 일반적으로 음용하는 수액은 목부수액을 뜻하 며, 이것은 무기염, 질소화합물, 탄수화물, 효소, 식물호르 몬 등이 용해되어있는 비교적 묽은 용액이다 $(4,5)$.

*Corresponding author. E-mail : jtjeon@foodkorea.com Phone : 82-70-8859-5624, Fax : 82-41-944-1629

Received 30 August 2016; Revised 4 October 2016; Accepted 1 May 2017.

Copyright (c) The Korean Society of Food Preservation. All rights reserved.
자작나무(Betula platyphylla)는 내한성이 강한 나무로 우 리나라에서는 중부이북지방의 산록에서 자라는 나무이다. 잎이 넓고 흰색인 나무껍질이 얇게 벗겨지기 때문에 나무를 모르는 사람들도 쉽게 알아 볼 수 있다(6). 자작나무는 자일 리톨 등의 원료로 사용되며, 청량감을 주며 치주질환을 예 방하고 당뇨병 치료제의 혈당치를 조절하거나 식품에 첨가 하고 있으며, 한방에서는 황달, 신장염, 폐결핵, 신경통, 위 염, 이뇨, 간경화 등에 요긴하게 사용되며, 수피에서부터 수액, 나무, 목질 및 그 수액을 먹고 기생하는 차가버섯까지 버릴 것이 없는 이로운 나무로 알려져 있다 $(7,8)$. 대체로 수액의 이동이 빠른 이름 봄에 한시적으로 채취하여 음용하 고 있으나, 자작나무 수액은 균이 번식하기 쉬운 영양 물질 을 함유하고 있기 때문에 쉽게 갈변되거나 세균오염 등의 문제로 신선한 상태의 수액을 소비자들에게 공급하는데 많은 어려움이 있어 저장기간을 늘리기 위해 채취 후 냉동 보관하고 있는 실정이다(9-11). 따라서 수액의 저장기간을 
연장하기 위한 적합한 가공 및 살균공정과 연구가 필요하다 고 판단된다. 가열 공정은 가장 일반적인 식품의 살균방법 이지만 영양성분 손실, 향미 변화 등의 근본적인 문제점이 있기 때문에 비가열 가공(non-thermal process)기술이 적용 되어야 한다(12). 비가열 가공에는 고전압 펄스 전기장 (pulsed electric field, PEF), ultraviolet(UV), irradiation, ultrasound, ozone, ohmic heating, high pressure processing (HPP) 등의 비가열처리 기술이 응용되고 있다(13). 그 중 최근 주목을 받고 있는 비가열 가공으로는 HPP 기술이 있는데(14), 이는 높은 압력을 이용하여 압력매체로 순간적 인 압력을 균일하게 전달시키는 정수압의 원리로 식품 살균 효과 뿐만 아니라 식품의 영양성분, 색, 향과 연관된 화학적 반응의 영향이 최소화 되어 제품의 품질변화가 거의 없어 식품의 특성을 살리며, 유통기한 연장의 이점을 볼 수 있는 기술로 근래 상업적으로 각광받고 있다(15,16). 2000년대 이후로 신선함과 천연을 강조하는 보존료 무첨가 육가공 품, 과채가공품 및 프리미엄 과채주스 중심으로 적용이 확 산되고 있으며 고품질 구현을 위한 보편화된 기술로 사용되 고 있지만(17), 수액의 저장성 증진을 위한 HPP 연구는 아직 보고된 바 없다.

따라서 본 연구에서는 자작나무 수액의 저장성을 향상시 키기 위한 방법으로 HPP 기술을 이용하여 HPP 처리 전후의 이화학적 변화를 관찰하고, 수액을 상업적으로 이용할 경 우 가장 중요한 지표인 저장기간 및 온도에 따른 미생물 및 품질특성 변화를 살펴보고자 하였다.

\section{재료 및 방법}

\section{실험재료}

본 연구에서 사용된 자작나무수액(birch sap)은 SK임업 (충북 충주시 산천면 명성리 인등산 자작나무 조림지)으로 부터 제공받아 연구를 진행하였고, 자작나무 수액은 채취 하여 $1 \mu \mathrm{m} \mathrm{1차} \mathrm{여과,} 0.45 \mu \mathrm{m} 2$ 차 여과, UV 살균 처리 후 $-20^{\circ} \mathrm{C}$ 에서 냉동 보관된 것을 해동하여 실험에 사용하였 다.

\section{High pressure processing(HPP) 조건 설정}

저장성 시험에 들어가기 전 HPP(Hyperbaric 135, N.C. Hyperbaric, S.A., Burgos, Spain) 처리 기준을 설정하기 위해 아래 Table 1 과 같이 5 가지의 처리방법을 통해 $5^{\circ} \mathrm{C}$ 의 저장고 에서 1 차 예비 실험을 실시하고 그 결과에 따라 본 저장성 실험은 $\mathrm{HPP}$ 처리 전후 자작나무 수액을 $130 \mathrm{~mL}$ 씩 멸균용 기에 담아 밀봉한 후 약 $10^{\circ} \mathrm{C}$ 의 물을 유입시켜 $550 \mathrm{MPa}$, $120 \mathrm{sec}$ 로 초고압 처리를 하여 $5^{\circ} \mathrm{C}$ 와 $10^{\circ} \mathrm{C}$ 의 저장고에 저장 하면서 저장기간에 따른 이화학 및 미생물학적 특성을 측정 하였다.
Table 1. Preliminary experimental test for set HPP conditions

\begin{tabular}{ccc}
\hline Sample $^{1)}$ & Pressure (MPa) & Time $(\mathrm{sec})$ \\
\hline Control & - & - \\
BS-1 & 550 & 30 \\
BS-2 & 550 & 60 \\
BS-3 & 500 & 60 \\
BS-4 & 500 & 120 \\
BS-5 & 450 & 120 \\
\hline
\end{tabular}

${ }^{1)}$ Control, non-treated birch sap; BS-1, birch sap treated with $550 \mathrm{MPa}$ pressure for 30 sec; BS-2, birch sap treated with $550 \mathrm{MPa}$ pressure for $60 \mathrm{sec}$; BS-3, birch sap treated with $500 \mathrm{MPa}$ pressure for $60 \mathrm{sec}$; BS-4, birch sap treated with 500 $\mathrm{MPa}$ pressure for $120 \mathrm{sec}$; BS-5, birch sap treated with $450 \mathrm{MPa}$ pressure for 120 sec.

당도 $\left({ }^{\circ} \mathrm{Brix}\right), \mathrm{pH}$ 및 산도 측정

자작나무 수액의 저장조건에 따른 당도 $\left({ }^{\circ} \mathrm{Brix}\right)$ 변화는 refractometer(RX-5000a, Atago Co., Ltd., Tokyo, Japan)를 $20^{\circ}$ 에서 측정하였다. $\mathrm{pH}$ 는 $\mathrm{pH}$ meter(Sevencompact ${ }^{\mathrm{TM}}$ $\mathrm{pH} / \mathrm{Ion}$ S220, Mettler Toledo AG, China)를 이용하여 3회 반복 측정하였다. 총 산도는 수액 $1 \mathrm{~mL}$ 를 취하여 $1 \%$ 페놀프 탈레인 용액을 지시약으로 하여 자동 적정기(Titroline ${ }^{\circledR}$ 5000 , SI Analytics FmbH, Germany)를 이용하여 $0.1 \mathrm{~N}$ $\mathrm{NaOH}$ 용액으로 자동 적정하였다. 소비된 $\mathrm{NaOH}$ 용액의 적 정량 $(\mathrm{mL})$ 을 수액의 주요 유기산인 malic acid로 환산하여 나타내었다.

\section{갈변도 및 탁도 측정}

자작나무 수액의 저장조건에 따른 갈변도 및 탁도 변화 는 UV-spectrophotometer(UV-1800 240V, Shimadzu, Kyoto, Japan)를 이용하여 갈변도(browning index)는 $420 \mathrm{~nm}$ 에서 그리고 탁도(turbidity)는 $590 \mathrm{~nm}$ 에서 각각의 흡광도를 측정 하였다(1).

색 도

자작나무 수액의 저장조건에 따른 색도는 표준흑색판 $(\mathrm{L}=0.00, \mathrm{a}=0.10, \mathrm{~b}=-0.05)$ 으로 보정된 색차계(CM-5, Konica Minolta, Ink, Japan)를 이용하여 명도(L, lightness), 적색도 (a, redness) 및 황색도(b, yellowness)값으로 나타내었다. HPP 처리전 시료를 기준으로하여 처리후의 변화로 나타내 었고, 표준백색판의 $\mathrm{L}, \mathrm{a}$ 및 b 값은 각각 $100.0,-0.01,0.00$ 이 었다. 한편 시료간의 색도차이를 나타내는 $\Delta \mathrm{E}$ (total color difference) 값은 다음의 식을 이용하여 계산하였다(23).

일반세균, 대장균군, 대장균, 진균 측정

자작나무수액의 저장조건에 따른 일반세균, 대장균군, 진균 측정에 사용된 검체의 채취 및 취급은 식품공전법에 따라 실시하였다. 자작나무 수액을 원액 또는 멸균된 $0.85 \%$ saline을 가하여 연속적으로 희석을 하여 plate count agar 
(PCA, Difco, Franklin Lakes, NJ, USA), desoxycholate lactose agar(DCLA, Difco, Franklin Lakes, NJ, USA), potato dextrose agar(PDA, Difco) 배지에 pour plate법으로 접종하 여 $36^{\circ} \mathrm{C}$ 에서 약 48 시간 배양한 후 $15-300$ 개의 집락을 생성 한 평판을 택하여 colony 수를 계측하여 측정하여 colony forming unit(log CFU)으로 표시하였고, 대장균은 정성시험 으로 EC broth 배지를 이용하여 24시간 배양 후 gas가 생성 된 것을 확인하여 균의 생육 여부를 확인하여 음성 (negative)/양성(positive)으로 표시하였다.

\section{통계분석}

실험 결과는 통계 프로그램 SPSS(18.0, SPSS Inc., Chicago, IL, USA)를 이용하여 평균값과 표준오차를 산출 하였고, 저장기간에 따른 이화학적 변화의 유의적 차이비 교를 위해 Duncan's multiple range test로 $\mathrm{p}<0.05$ 수준에서 시료간의 유의적인 차이를 검증하였다.

\section{결과 및 고찰}

자작나무 수액의 품질 변화에 따른 최적 조건 설정

압력 450-550 MPa, 처리 시간 30-120 sec 등의 다양한 조건으로 $\mathrm{HPP}$ 처리한 자작나무수액을 $5^{\circ} \mathrm{C}$ 의 냉장조건에서 63 일 동안 저장하면서 살펴본 이화학적 변화는 Table 2 와 Fig. 1과 같다. 당도는 저장기간 중 control 및 $\mathrm{HPP}$ 조건에서 1.2-1.4 ${ }^{\circ} \mathrm{Brix}$ 의 범위로 큰 변화가 없었지만, HPP 미처리군 의 $\mathrm{pH}$ 는 5.86에서 4.39로 감소하는 경향을 보였고 산도는 $0.042 \%$ 에서 $0.121 \%$ 까지 증가하는 경향을 보였다. 수액을 저장하면서 15 일간 $\mathrm{pH}$ 변화를 살펴본 결과 control군은 그 변화폭이 0.3-0.5인데 반하여 HPP 처리군은 0.04-0.1로 그 변화폭이 미세하게 나타났다. Kim 등(19)은 저장성 향상을 위해 열처리를 하는 경우보다 HPP 처리를 하였을 때 화학 적인 변화가 크게 일어나지 않는다고 하였다. 특히 control 군의 $\mathrm{pH}$ 는 초기 5.86에서 63일간 저장 후 4.39로 매우 큰 변화를 보였으나 $500 \mathrm{MPa}$ 에서 $120 \mathrm{sec}$ 실시한 $\mathrm{HPP}$ 처리군 은 처리 직 후 6.04 에서 63 일간 저장 후 5.70으로 $\mathrm{pH}$ 변화가 적게 나타났다. 이러한 경향은 Shin 등(10)의 한외여과방법 을 이용한 자작나무 수액의 저장성 연구에서 한외여과 처리 군과 미처리군의 정도의 차이는 있었지만 같은 현상을 나타 내었는데 자작나무 수액을 저장하는 동안 $\mathrm{pH}$ 감소 현상이 있었다는 보고와 일치하는 결과를 보였다. 이는 음용수와 는 달리 자작나무 수액에 존재하는 유기산 및 단백질 등의 영양 성분 등이 많아 미생물의 증식으로 인한 유기산 증가 로 $\mathrm{pH}$ 가 낮아지고 산도가 증가하는 결과가 나타나는 것으 로 사료된다.

자작나무 수액의 $\mathrm{HPP}$ 처리 후 저장 기간 동안 $\mathrm{pH}$, 갈변도 및 탁도의 변화 양상은 Fig. 1과 같다. 다양한 HPP 처리
조건 중 $\mathrm{BS}-3$ 군이 다른 조건에 비해 $\mathrm{pH}$, 갈변도 및 탁도의 변화가 가장 적게 나타나 자작나무 수액을 $500 \mathrm{MPa}, 120$ $\mathrm{sec}$ 의 처리 조건에서 처리하는 것이 이화학적 변화를 최소 화하는 적정 조건으로 평가하였다.

또한, 다양한 영양물질을 함유한 수액의 저장유통상 단 점은 미생물 증식이라고 할 수 있는데 다양한 HPP 조건에 따른 미생물을 확인한 결과를 Table 3에 나타내었다. Control의 경우 초기 미생물이 $4.19 \log \mathrm{CFU}$ 에서 6일 후에 는 $6.34 \log \mathrm{CFU}$ 까지 증가되었다. 일반세균의 경우 15 일까 지 약 $1 \log \mathrm{CFU}$ 의 수준에서는 검출되지 않았으며, HPP 처리 후 초반에는 세포 미세구조의 변화를 일으켜 기능적 손실을 야기하여 사멸되고(12), 저장일이 길어질수록 손상 된 세포막을 회복하는 일반세균이 발생함에 따라 상이하게

Table 2. Changes in physicochemical properties of birch sap treated under various HPP conditions during cold storage at $5^{\circ} \mathrm{C}$

\begin{tabular}{|c|c|c|c|c|}
\hline Sample ${ }^{1)}$ & $\begin{array}{l}\text { Storage period } \\
\text { (day) }\end{array}$ & $\begin{array}{l}\text { Sugar contents } \\
\left({ }^{\circ} \text { Brix }\right)\end{array}$ & Total acidity (\%) & $\mathrm{pH}$ \\
\hline \multirow{4}{*}{ Control } & 1 & $1.4 \pm 0.1^{\mathrm{ab}}$ & $0.042 \pm 0.004^{\mathrm{a}}$ & $5.86 \pm 0.00^{\mathrm{d}}$ \\
\hline & 6 & $1.4 \pm 0.0^{\mathrm{b}}$ & $0.045 \pm 0.004^{\mathrm{a}}$ & $5.53 \pm 0.00^{c}$ \\
\hline & 15 & $1.3 \pm 0.1^{\mathrm{ab}}$ & $0.062 \pm 0.004^{b}$ & $4.99 \pm 0.00^{\mathrm{b}}$ \\
\hline & 63 & $1.3 \pm 0.0^{\mathrm{a}}$ & $0.121 \pm 0.007^{\mathrm{c}}$ & $4.39 \pm 0.00^{\mathrm{a}}$ \\
\hline \multirow{4}{*}{ BS-1 } & 1 & $1.3 \pm 0.0^{\mathrm{b}}$ & $0.042 \pm 0.004^{\mathrm{a}}$ & $6.04 \pm 0.00^{\mathrm{d}}$ \\
\hline & 6 & $1.3 \pm 0.1^{\mathrm{b}}$ & $0.040 \pm 0.000^{\mathrm{a}}$ & $5.98 \pm 0.01^{\mathrm{c}}$ \\
\hline & 15 & $1.3 \pm 0.1^{\mathrm{b}}$ & $0.045 \pm 0.004^{\mathrm{a}}$ & $5.85 \pm 0.01^{b}$ \\
\hline & 63 & $1.2 \pm 0.1^{\mathrm{a}}$ & $0.045 \pm 0.004^{\mathrm{a}}$ & $5.38 \pm 0.00^{\mathrm{a}}$ \\
\hline \multirow{4}{*}{ BS-2 } & 1 & $1.3 \pm 0.0^{\mathrm{b}}$ & $0.025 \pm 0.004^{\mathrm{a}}$ & $6.04 \pm 0.00^{\mathrm{d}}$ \\
\hline & 6 & $1.4 \pm 0.1^{\mathrm{b}}$ & $0.027 \pm 0.000^{\mathrm{a}}$ & $5.98 \pm 0.01^{\mathrm{c}}$ \\
\hline & 15 & $1.3 \pm 0.0^{\mathrm{b}}$ & $0.029 \pm 0.004^{\mathrm{a}}$ & $5.86 \pm 0.00^{\mathrm{b}}$ \\
\hline & 63 & $1.2 \pm 0.1^{\mathrm{a}}$ & $0.038 \pm .003^{\mathrm{b}}$ & $5.65 \pm 0.00^{\mathrm{a}}$ \\
\hline \multirow{4}{*}{ BS-3 } & 1 & $1.3 \pm 0.1^{\mathrm{b}}$ & $0.027 \pm 0.004^{\mathrm{a}}$ & $6.04 \pm 0.00^{\mathrm{d}}$ \\
\hline & 6 & $1.4 \pm 0.1^{\mathrm{c}}$ & $0.027 \pm 0.004^{\mathrm{a}}$ & $5.98 \pm 0.02^{c}$ \\
\hline & 15 & $1.4 \pm 0.1^{\mathrm{bc}}$ & $0.042 \pm 0.000^{\mathrm{b}}$ & $5.86 \pm 0.02^{b}$ \\
\hline & 63 & $1.2 \pm 0.1^{\mathrm{a}}$ & $0.058 \pm 0.000^{c}$ & $5.04 \pm 0.03^{\mathrm{a}}$ \\
\hline \multirow{4}{*}{ BS-4 } & 1 & $1.3 \pm 0.1^{\mathrm{a}}$ & $0.025 \pm 0.004^{\mathrm{a}}$ & $6.04 \pm 0.00^{\mathrm{d}}$ \\
\hline & 6 & $1.3 \pm 0.1^{\mathrm{a}}$ & $0.025 \pm 0.004^{\mathrm{a}}$ & $5.98 \pm 0.02^{\mathrm{c}}$ \\
\hline & 15 & $1.3 \pm 0.1^{\mathrm{a}}$ & $0.027 \pm .000^{\mathrm{a}}$ & $5.86 \pm 0.02^{b}$ \\
\hline & 63 & $1.2 \pm 0.1^{\mathrm{a}}$ & $0.040 \pm 0.000^{\mathrm{b}}$ & $5.70 \pm 0.01^{\mathrm{a}}$ \\
\hline \multirow{4}{*}{ BS-5 } & 1 & $1.3 \pm 0.1^{\mathrm{ab}}$ & $0.025 \pm 0.004^{\mathrm{a}}$ & $6.05 \pm 0.01^{\mathrm{d}}$ \\
\hline & 6 & $1.3 \pm 0.1^{\mathrm{b}}$ & $0.040 \pm 0.000^{\mathrm{b}}$ & $6.00 \pm 0.01^{\mathrm{c}}$ \\
\hline & 15 & $1.4 \pm 0.1^{\mathrm{ab}}$ & $0.040 \pm 0.000^{\mathrm{b}}$ & $5.87 \pm 0.01^{b}$ \\
\hline & 63 & $1.2 \pm 0.0^{\mathrm{a}}$ & $0.065 \pm 0.004^{\mathrm{c}}$ & $4.88 \pm 0.02^{\mathrm{a}}$ \\
\hline
\end{tabular}

${ }^{1)}$ Control, non-treated birch sap; BS-1, birch sap treated with $550 \mathrm{MPa}$ pressure for $30 \mathrm{sec}$; BS-2, birch sap treated with $550 \mathrm{MPa}$ pressure for $60 \mathrm{sec}$; BS-3, birch sap treated with $500 \mathrm{MPa}$ pressure for $60 \mathrm{sec}$; BS-4, birch sap treated with 500 $\mathrm{MPa}$ pressure for $120 \mathrm{sec}$; BS-5, birch sap treated with $450 \mathrm{MPa}$ pressure for 120 sec.

${ }^{2)}$ Means \pm SD ( $n=3$ ) with different superscript in the each column (HPP condition group) are significantly different $(p<0.05)$ by Duncan's multiple range test. 

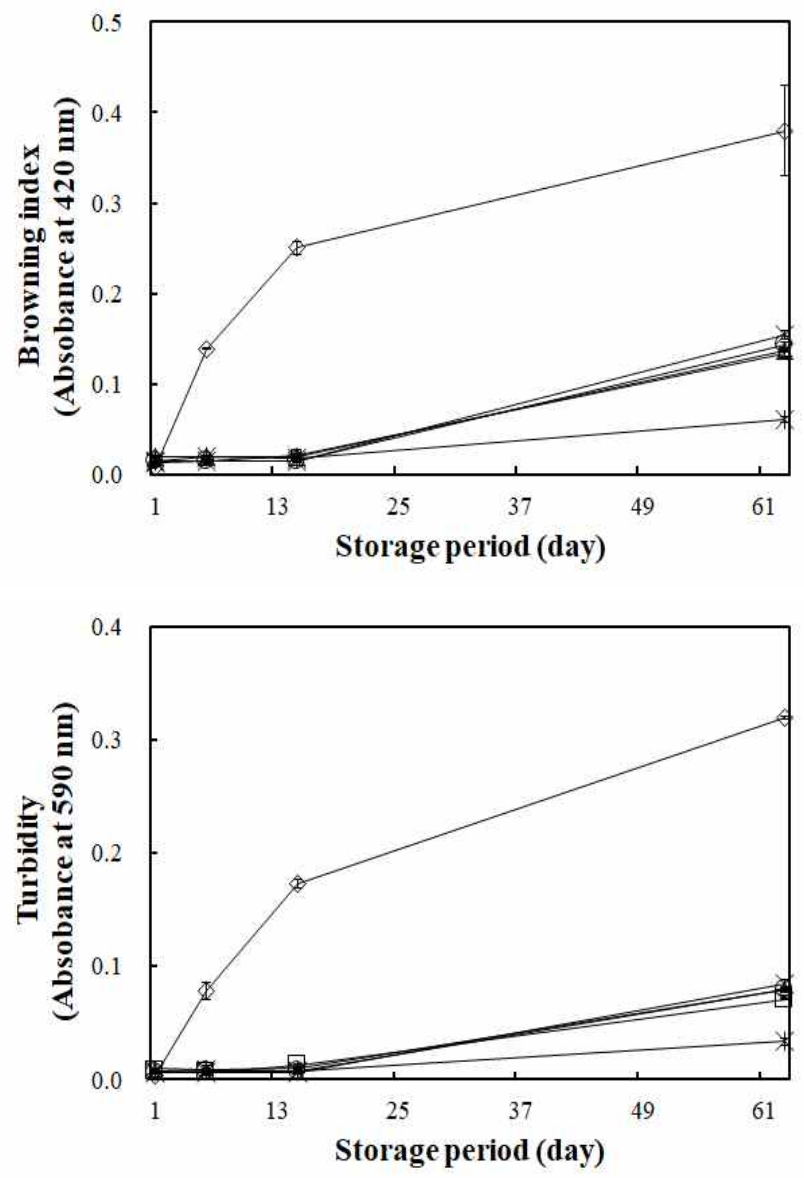

Fig. 1. Changes in browning index and turbidity of birch sap treated under various HPP conditions during cold storage at $5^{\circ} \mathrm{C}$.

$\diamond-\diamond$, Control, non-treated birch sap; $\square-\square$, BS-1, birch sap treated with 550 $\mathrm{MPa}$ pressure for $30 \mathrm{sec} ; \triangle-\triangle$, BS-2, birch sap treated with $550 \mathrm{MPa}$ pressure for $60 \mathrm{sec} ; \times-x, \mathrm{BS}-3$, birch sap treated with $500 \mathrm{MPa}$ pressure for $60 \mathrm{sec}$; *-*, BS-4, birch sap treated with $500 \mathrm{MPa}$ pressure for $120 \mathrm{sec}$; $\bigcirc-\bigcirc$, BS-5, Birch sap treated with $450 \mathrm{MPa}$ pressure for $120 \mathrm{sec}$.

Values are means $\pm \mathrm{SD}$ of triplicate determinations.

측정되는 것으로 판단된다. 대장균의 오염은 없었지만 대 장균군이 검출되었고 저장기간이 증가될수록 더 증식되는 것을 확인 할 수 있었다. 반면에 HPP 처리군의 처리 직후 일반세균은 $1 \log \mathrm{CFU}$ 이하로 나타났으며, 대장균군은 검 출되지 않아 완전하게 제어된 것으로 나타났다. 다양한 $\mathrm{HPP}$ 처리군 중 $5^{\circ} \mathrm{C}$ 의 냉장보관 조건에서의 일반세균에 대 한 제어능력은 63 일간 저장 후의 결과를 볼 때 BS-4와 BS-5 가 미생물학적으로 매우 안정한 값을 보였다.

자작나무수액은 식품공전의 식품별 기준 및 규격(고시 제2016-64호)에서 기타음료로써 일반세균수 $2 \log \mathrm{CFU}$ 이 하로 규정되어 있으며(18) 상업적으로 이용되기 위해서는 일반세균이 가장 큰 지표 기준이 되어야한다. BS-1, BS-2, $\mathrm{BS}-3$ 의 일반세균 값은 $2 \log \mathrm{CFU}$ 이상으로 기준을 초과하 여 규격에 맞지 않아 조건이 적합하지 않고, BS-4, BS-5 두 조건은 각각 $500 \mathrm{MPa}$ 와 $450 \mathrm{MPa}$ 로 압력은 다르지만 동일한 처리 시간인 $120 \mathrm{sec}$ 에서 일반세균 $\mathrm{g} \log \mathrm{CFU}$ 이하
로 식품별 규격에 적합한 결과를 보였다.

종합적으로 예비실험에서는 $500 \mathrm{Mpa}$ 에서 $120 \mathrm{sec}, 450$ $\mathrm{Mpa}$ 에서 $120 \mathrm{sec}$ 의 두 조건에서 이화학 및 미생물의 제어 에서 가장 큰 효과가 나타났지만, Chen 등(21)에서 초고압 처리 조건을 달리한 파파야 음료의 품질변화를 살펴보았을 때 HPP 처리시간이 길어질수록, 그리고 압력이 높을수록 미생물의 세포막 구조의 손상이 커짐으로써 제어능력이 높다는 연구결과에 따라 자작나무 수액의 이화학적 및 미생 물학적 안전성에 최대의 효과를 보기 위하여 $550 \mathrm{MPa}, 120$ $\sec$ 의 최대 압력으로 다음 실험을 실시하였다.

Table 3. Changes in microorganism of birch sap treated under various HPP conditions during storage at $5^{\circ} \mathrm{C}$

(unit: $\log \mathrm{CFU}$ )

\begin{tabular}{|c|c|c|c|c|c|}
\hline \multirow{2}{*}{$\begin{array}{l}\text { Micro- } \\
\text { organism }\end{array}$} & \multirow{2}{*}{ Sample ${ }^{1)}$} & \multicolumn{4}{|c|}{ Storage period (day) } \\
\hline & & 1 & 6 & 15 & 63 \\
\hline \multirow{6}{*}{$\begin{array}{c}\text { Total } \\
\text { bacteria }\end{array}$} & Control & $4.19 \pm 0.01^{2)}$ & $6.34 \pm 0.04$ & - & - \\
\hline & BS-1 & $0.54 \pm 0.06$ & $\mathrm{ND}^{3)}$ & ND & $3.89 \pm 0.01$ \\
\hline & BS-2 & $0.50 \pm 0.20$ & $0.69 \pm 0.09$ & ND & $3.47 \pm 0.02$ \\
\hline & BS-3 & $0.30 \pm 0.00$ & ND & $0.24 \pm 0.24$ & $3.50 \pm 0.07$ \\
\hline & BS-4 & $0.45 \pm 0.15$ & $0.98 \pm 0.02$ & $0.30 \pm 0.00$ & ND \\
\hline & BS-5 & $0.77 \pm 0.07$ & $1.15 \pm 0.11$ & ND & $1.24 \pm 0.01$ \\
\hline \multirow{6}{*}{$\begin{array}{c}\text { Coliform } \\
\text { group }\end{array}$} & Control & $0.80 \pm 0.10$ & $1.47 \pm 0.01$ & - & - \\
\hline & BS-1 & $\mathrm{ND}$ & ND & ND & $\mathrm{ND}$ \\
\hline & BS-2 & $\mathrm{ND}$ & ND & ND & ND \\
\hline & BS-3 & ND & ND & ND & ND \\
\hline & BS-4 & $\mathrm{ND}$ & $\mathrm{ND}$ & ND & ND \\
\hline & BS-5 & ND & ND & ND & $\mathrm{ND}$ \\
\hline \multirow{6}{*}{ E.coil } & Control & Negative & Negative & - & - \\
\hline & BS-1 & Negative & Negative & Negative & Negative \\
\hline & BS-2 & Negative & Negative & Negative & Negative \\
\hline & BS-3 & Negative & Negative & Negative & Negative \\
\hline & BS-4 & Negative & Negative & Negative & Negative \\
\hline & BS-5 & Negative & Negative & Negative & Negative \\
\hline
\end{tabular}

${ }^{1)}$ Control, non-treated birch sap; BS-1, birch sap treated with $550 \mathrm{MPa}$ pressure for $30 \mathrm{sec}$; BS-2, birch sap treated with $550 \mathrm{MPa}$ pressure for $60 \mathrm{sec}$; BS-3, birch sap treated with $500 \mathrm{MPa}$ pressure for $60 \mathrm{sec}$; BS-4, birch sap treated with 500 $\mathrm{MPa}$ pressure for $120 \mathrm{sec}$; BS-5, birch sap treated with $450 \mathrm{MPa}$ pressure for 120 sec.

${ }^{2)}$ All results are expressed as means for three replicates.

${ }^{3)} \mathrm{ND}$, Not detected.

저장온도에 따른 수액의 이화학적 변화

최적 조건 설정 결과로 설정된 $\mathrm{HPP}$ 조건인 $550 \mathrm{MPa}$, $120 \mathrm{sec}$ 으로 자작나수 수액을 처리하였고, $5^{\circ} \mathrm{C}$ 와 $10^{\circ} \mathrm{C}$ 각각 의 조건에서 저장하면서 이화학 변화를 관찰하였다(Table $4,5) .5^{\circ} \mathrm{C}$ 에 저장한 HPP 미처리군 C-5의 $\mathrm{pH}$ 는 초기 5.69 에 서 13 일간 저장 후에는 4.96 으로 급격히 감소되었고, 산도 
는 13 일간 저장하는 동안 $0.013 \%$ 에서 $0.085 \%$ 로 증가하는 추세를 보였다. 탁도는 초기에 0.014 에서 저장 13 일째에는 10 배인 0.140 까지 증가하였고, 갈변도 또한 초기에 0.031 에 서 저장 13 일째에는 0.238 까지 급격히 증가되는 것을 확인 할 수 있었다. 하지만, HPP 처리군인 H-5는 초기에 $\mathrm{pH} 5.59$ 에서 13 일까지 5.55 으로 거의 변화가 없었고 그래프에 나타 내지 않았지만 45 일 저장일까지 5.49 로 $\mathrm{pH}$ 의 변화가 크지 않았다. 산도 1 일차 $0.022 \%$ 에서 13 일차 $0.042 \%$ 으로 처리군 보다 완만한 증가를 보였다. 탁도 및 갈변도 또한 $\mathrm{HPP}$ 미처 리 군은 0.014 에서 $0.140,0.031$ 에서 0.238 로 급격히 증가하 였지만, HPP 처리군은 1 일차 탁도 0.024 에서 0.020 , 갈변도

Table 4. Changes in physicochemical properties of birch sap treated under HPP conditions during cold storage at 5 and $10^{\circ} \mathrm{C}$

\begin{tabular}{ccccc}
\hline Sample $^{1)}$ & $\begin{array}{c}\text { Storage period } \\
\text { (day) }\end{array}$ & $\begin{array}{c}\text { Sugar contents } \\
\left({ }^{\circ} \text { Brix }\right)\end{array}$ & $\begin{array}{c}\text { Total acidity } \\
(\%)\end{array}$ & $\mathrm{pH}$ \\
\hline \multirow{2}{*}{$\mathrm{C}-5$} & 1 & $1.35 \pm 0.00^{2)(3)}$ & $0.013 \pm 0.000^{\mathrm{a}}$ & $5.69 \pm 0.03^{\mathrm{d}}$ \\
& 13 & $1.24 \pm 0.00^{\mathrm{a}}$ & $0.085 \pm 0.003^{\mathrm{d}}$ & $4.96 \pm 0.03^{\mathrm{a}}$ \\
\hline \multirow{2}{*}{$\mathrm{H}-5$} & 1 & $1.26 \pm 0.00^{\mathrm{ab}}$ & $0.022 \pm 0.003^{\mathrm{b}}$ & $5.59 \pm 0.00^{\mathrm{c}}$ \\
& 13 & $1.27 \pm 0.01^{\mathrm{b}}$ & $0.045 \pm 0.003^{\mathrm{c}}$ & $5.55 \pm 0.00^{\mathrm{b}}$ \\
\hline \multirow{2}{*}{$\mathrm{C}-10$} & 1 & $1.33 \pm 0.02^{\mathrm{c}}$ & $0.015 \pm 0.003^{\mathrm{a}}$ & $5.69 \pm 0.00^{\mathrm{d}}$ \\
& 13 & $1.14 \pm 0.01^{\mathrm{a}}$ & $0.121 \pm 0.004^{\mathrm{c}}$ & $4.17 \pm 0.03^{\mathrm{a}}$ \\
\hline \multirow{2}{*}{$\mathrm{H}-10$} & 1 & $1.27 \pm 0.01^{\mathrm{b}}$ & $0.025 \pm 0.004^{\mathrm{a}}$ & $5.60 \pm 0.00^{\mathrm{c}}$ \\
& 13 & $1.25 \pm 0.02^{\mathrm{b}}$ & $0.045 \pm 0.007^{\mathrm{b}}$ & $5.54 \pm 0.00^{\mathrm{b}}$ \\
\hline
\end{tabular}

${ }^{1)} \mathrm{C}-5$, non-treated birch sap during storage at $5^{\circ} \mathrm{C}$; $\mathrm{H}-5$, birch sap treated with 550 $\mathrm{MPa}$ pressure for $120 \mathrm{sec}$ during storage at $5^{\circ} \mathrm{C}$; $\mathrm{C}-10$, non-treated birch sap during storage at $10^{\circ} \mathrm{C} ; \mathrm{H}-10$, birch sap treated with $550 \mathrm{MPa}$ pressure for $120 \mathrm{sec}$ during storage at $10^{\circ} \mathrm{C}$.

${ }^{2)}$ Values are means \pm SD of triplicate determinations.

${ }^{3}$ Different superscripts within the each column (storage temperature groups) indicate significant differences $(p<0.05)$.

Table 5. Changes in browning index and turbidity of birch sap treated under HPP conditions during cold storage at 5 and $10^{\circ} \mathrm{C}$

\begin{tabular}{cccc}
\hline Sample $^{1)}$ & Storage period (day) & Browning index & Turbidity \\
\hline \multirow{2}{*}{ C-5 } & 1 & $0.031 \pm 0.00^{22 \mathrm{a} 3)}$ & $0.014 \pm 0.002^{\mathrm{a}}$ \\
& 13 & $0.238 \pm 0.005^{\mathrm{b}}$ & $0.140 \pm 0.005^{\mathrm{c}}$ \\
\hline \multirow{2}{*}{$\mathrm{H}-5$} & 1 & $0.039 \pm 0.001^{\mathrm{a}}$ & $0.024 \pm 0.001^{\mathrm{b}}$ \\
& 13 & $0.039 \pm 0.005^{\mathrm{a}}$ & $0.020 \pm 0.001^{\mathrm{ab}}$ \\
\hline \multirow{2}{*}{$\mathrm{C}-10$} & 1 & $0.031 \pm 0.002^{\mathrm{a}}$ & $0.014 \pm 0.002^{\mathrm{a}}$ \\
& 13 & $0.332 \pm 0.001^{\mathrm{c}}$ & $0.191 \pm 0.004^{\mathrm{b}}$ \\
\hline \multirow{2}{*}{$\mathrm{H}-10$} & 1 & $0.056 \pm 0.006^{\mathrm{b}}$ & $0.021 \pm 0.004^{\mathrm{a}}$ \\
& 13 & $0.033 \pm 0.002^{\mathrm{a}}$ & $0.015 \pm 0.006^{\mathrm{a}}$ \\
\hline
\end{tabular}

${ }^{10} \mathrm{C}-5$, non-treated birch sap during storage at $5^{\circ} \mathrm{C} ; \mathrm{H}-5$, birch sap treated with 550 $\mathrm{MPa}$ pressure for $120 \mathrm{sec}$ during storage at $5^{\circ} \mathrm{C} ; \mathrm{C}-10$, non-treated birch sap during storage at $10^{\circ} \mathrm{C} ; \mathrm{H}-10$, birch sap treated with $550 \mathrm{MPa}$ pressure for $120 \mathrm{sec}$ during storage at $10^{\circ} \mathrm{C}$.

${ }^{2)}$ Values are means $\pm \mathrm{SD}$ of triplicate determinations.

${ }^{3}$ Different superscripts within the each column (storage temperature groups) indicate significant differences $(\mathrm{p}<0.05)$.
1 일차 0.039 에서 18 일차 0.040 으로 거의 변화가 없었다.

이러한 결과는 Park 등(22)이 초고압 처리한 대추술을 60 일간 저장하면서 품질변화를 살펴본 결과 무처리 및 냉 동 처리한 술의 경우 $\mathrm{pH}$ 및 산도의 변화가 크게 일어났으나 HPP 처리한 술의 경우 이화학적인 변화가 거의 일어나지 않았다는 결과와도 일치하는 내용이다.

$10^{\circ} \mathrm{C}$ 에 저장한 control 군인 C-10도 $5^{\circ} \mathrm{C}$ 에서 저장한 경우 와 동일하게 초기 $\mathrm{pH} 5.69$ 에서 13 일간 저장 후에는 $\mathrm{pH}$ 4.17 까지 감소되어 $5^{\circ} \mathrm{C}$ 에서 저장하였을 때보다 변화폭이 더 크게 감소하는 경향을 보였다. 그에 따라 산도, 탁도, 갈변도 또한 $5^{\circ} \mathrm{C}$ 보다 더 큰 변화를 보였으며, 산도는 $0.015 \%$ 에서 $0.121 \%$ 까지 증가되고, 탁도는 초기 0.014 에서 13 일 저장 후 0.191 까지 증가되었다. 갈변도도 0.031 에서 0.332 까지 약 10 배 이상으로 급격하게 높아졌다. 데이터를 나타내지 않았지만 $\mathrm{HPP}$ 처리군인 $\mathrm{H}-10$ 은 $10^{\circ} \mathrm{C}$ 의 저장조건 에서 24일 동안 $\mathrm{pH}$ 는 5.60-5.50, 탁도 0.015-0.021, 갈변도 0.033-0.056으로 큰 변화 없이 안정된 값을 보여 이화학적으 로는 안정적인 값을 보였으나, 저장 28 일에는 ${ }^{\circ} \mathrm{Brix}$ 를 제외 한 항목 중 $\mathrm{pH}$ 는 4.96 으로 감소되고, 산도가 $0.078 \%$, 탁도 0.064 , 갈변도 0.122 으로 증가하였다. 수액의 저장기간 증가 에 따른 $\mathrm{pH}$ 감소 및 총 산도, 탁도, 갈변도의 증가는 수액 내에 존재하는 미생물이 증식하면서 유기산 및 대사물이 생성되었기 때문으로 판단된다(1).

\section{저장온도에 따른 수액의 색도 변화}

식품의 색 변화는 식품을 저장하거나 가공할 때 일어나 는 일반적인 현상으로 식품의 품질에 상당한 영향을 미친 다. 저장일 및 저장온도에 따른 색도를 측정한 결과는 Table 6과 같다. 자작나무 수액의 명도는 평균 99.34, 99.70, 적색 도는 평균 $-0.15,-0.03$, 황색도는 평균 $0.79,1.13$ 범위로 측정되었다. HPP 처리군인 H-5, H-10 두 조건 모두 저장기 간까지 큰 변화가 없었지만, control군은 저장일이 길어질수 록 명도는 감소하고, 적색도와 황색도는 증가하는 경향이 나타났다. 특히 b 값의 변화가 가장 크게 나타났는데 $5^{\circ} \mathrm{C}$ 에 저장한 C-5는 초기에 0.79 에서 저장 7 일째에는 0.83 , 저장 13 일째에는 1.56 으로 점차 증가되었고, $10^{\circ} \mathrm{C}$ 에 저장한 C-10 은 초기에 0.61 이었고, 저장 4 일째에는 $0.83,8$ 일째에는 $1.67,13$ 일째에는 2.22 로 전자보다 큰 변화의 폭을 보였다. 반면, $\mathrm{HPP}$ 처리로 인해 전반적으로 수액의 $\mathrm{L}$ 값은 $5{ }^{\circ} \mathrm{C}$ 에서 $99.22-99.43,10^{\circ} \mathrm{C}$ 에서 $99.19-99.37, \mathrm{a}$ 값은 $5^{\circ} \mathrm{C}$ 에서 $-0.03-0.00,10^{\circ} \mathrm{C}-0.03-0.03$ 으로 큰 변화가 없었고 다만, $\mathrm{b}$ 값이 1 일차 1.18 에서 28 동안 저장기간이 길어짐에 따라 1.36 으로 약간 증가하였다. 전체적으로 $5^{\circ} \mathrm{C}$ 와 $10^{\circ} \mathrm{C}$ 에 저장 하는 동안 색도의 차이는 크지 않아 품질에 큰 영향을 끼치 지는 않았다. Park 등(22)은 대추술을 저장하였을 때의 색변 화의 원인 중 살균 부족으로 인한 잔존 미생물의 대사물이 색도의 영향을 미친다고 하였는데 HPP 처리 미생물 증 
Table 6. Effect of HPP on color in birch sap during storage at 5 and $10^{\circ} \mathrm{C}$

\begin{tabular}{|c|c|c|c|c|c|}
\hline \multirow{2}{*}{ Sample ${ }^{1)}$} & \multirow{2}{*}{ Storage period (day) } & \multicolumn{4}{|c|}{ Hunter's parameter } \\
\hline & & L (lightness) & a (redness) & $\mathrm{b}$ (yellowness) & $\Delta \mathrm{E}$ \\
\hline \multirow{3}{*}{ C-5 } & 1 & $99.70 \pm 0.02^{2)(3)}$ & $-0.15 \pm 0.04^{\mathrm{a}}$ & $0.79 \pm 0.02^{\mathrm{a}}$ & - \\
\hline & 7 & $99.63 \pm 0.02^{\mathrm{b}}$ & $-0.03 \pm 0.02^{\mathrm{b}}$ & $0.83 \pm 0.05^{\mathrm{a}}$ & 0.14 \\
\hline & 13 & $99.49 \pm 0.02^{\mathrm{a}}$ & $0.13 \pm 0.02^{\mathrm{c}}$ & $1.56 \pm 0.01^{b}$ & 0.85 \\
\hline \multirow{9}{*}{ H-5 } & 1 & $99.34 \pm 0.01^{\text {bcd }}$ & $-0.03 \pm 0.02^{\mathrm{ab}}$ & $1.13 \pm 0.02^{\mathrm{a}}$ & - \\
\hline & 7 & $99.32 \pm 0.03^{\mathrm{abc}}$ & $-0.03 \pm 0.02^{\mathrm{ab}}$ & $1.14 \pm 0.02^{\mathrm{a}}$ & 0.03 \\
\hline & 13 & $99.29 \pm 0.06^{\mathrm{abc}}$ & $-0.04 \pm 0.01^{\mathrm{a}}$ & $1.15 \pm 0.03^{\mathrm{ab}}$ & 0.06 \\
\hline & 18 & $99.28 \pm 0.03^{\mathrm{abc}}$ & $0.00 \pm 0.01^{\mathrm{b}}$ & $1.20 \pm 0.02^{\mathrm{bc}}$ & 0.10 \\
\hline & 24 & $99.26 \pm 0.05^{\mathrm{abc}}$ & $-0.03 \pm 0.02^{\mathrm{ab}}$ & $1.15 \pm 0.02^{\mathrm{ab}}$ & 0.09 \\
\hline & 30 & $99.22 \pm 0.11^{\mathrm{a}}$ & $-0.03 \pm 0.01^{\mathrm{ab}}$ & $1.20 \pm 0.03^{\mathrm{bc}}$ & 0.14 \\
\hline & 36 & $99.37 \pm 0.04^{\text {cd }}$ & $-0.01 \pm 0.02^{\mathrm{ab}}$ & $1.23 \pm 0.06^{\mathrm{cd}}$ & 0.11 \\
\hline & 42 & $99.43 \pm 0.08^{\mathrm{d}}$ & $-0.01 \pm 0.02^{\mathrm{ab}}$ & $1.22 \pm 0.03^{\mathrm{c}}$ & 0.13 \\
\hline & 45 & $99.25 \pm 0.07^{\mathrm{ab}}$ & $-0.01 \pm 0.03^{a b}$ & $1.28 \pm 0.04^{\mathrm{d}}$ & 0.18 \\
\hline \multirow{4}{*}{ C-10 } & 1 & $99.75 \pm 0.03^{2(c) 3)}$ & $-0.13 \pm 0.03^{\mathrm{a}}$ & $0.61 \pm 0.03^{\mathrm{a}}$ & - \\
\hline & 4 & $99.69 \pm 0.01^{c}$ & $-0.06 \pm 0.01^{b}$ & $0.83 \pm 0.02^{\mathrm{b}}$ & 0.24 \\
\hline & 8 & $99.26 \pm 0.04^{b}$ & $0.14 \pm 0.03^{\mathrm{c}}$ & $1.67 \pm 0.01^{\mathrm{c}}$ & 1.20 \\
\hline & 13 & $98.70 \pm 0.18^{\mathrm{a}}$ & $0.30 \pm 0.02^{\mathrm{d}}$ & $2.22 \pm 0.01^{\mathrm{d}}$ & 1.97 \\
\hline \multirow{8}{*}{$\mathrm{H}-10$} & 1 & $99.26 \pm 0.05^{\mathrm{ab}}$ & $-0.03 \pm 0.02^{\mathrm{ab}}$ & $1.18 \pm 0.06^{\mathrm{a}}$ & - \\
\hline & 4 & $99.19 \pm 0.05^{\mathrm{a}}$ & $-0.04 \pm 0.01^{\mathrm{ab}}$ & $1.19 \pm 0.01^{\mathrm{a}}$ & 0.07 \\
\hline & 8 & $99.20 \pm 0.05^{\mathrm{a}}$ & $-0.05 \pm 0.02^{\mathrm{a}}$ & $1.15 \pm 0.02^{\mathrm{a}}$ & 0.07 \\
\hline & 13 & $99.33 \pm 0.08^{\mathrm{bc}}$ & $-0.03 \pm 0.02^{\mathrm{ab}}$ & $1.08 \pm 0.03^{\mathrm{a}}$ & 0.12 \\
\hline & 16 & $99.37 \pm 0.06^{\mathrm{c}}$ & $-0.02 \pm 0.03^{\mathrm{abc}}$ & $1.12 \pm 0.10^{\mathrm{a}}$ & 0.13 \\
\hline & 21 & $99.32 \pm 0.06^{\mathrm{bc}}$ & $0.01 \pm 0.02^{\mathrm{bc}}$ & $1.07 \pm 0.04^{\mathrm{a}}$ & 0.13 \\
\hline & 24 & $99.36 \pm 0.05^{\mathrm{bc}}$ & $0.03 \pm 0.04^{c}$ & $1.04 \pm 0.03^{\mathrm{a}}$ & 0.18 \\
\hline & 28 & $99.27 \pm 0.03^{\mathrm{abc}}$ & $-0.02 \pm 0.06^{\mathrm{d}}$ & $1.36 \pm 0.16^{b}$ & 0.26 \\
\hline
\end{tabular}

${ }^{1)} \mathrm{C}-5$, non-treated birch sap during storage at $5^{\circ} \mathrm{C}$; $\mathrm{H}-5$, birch sap treated with $550 \mathrm{MPa}$ pressure for $120 \mathrm{sec}$ during storage at $5^{\circ} \mathrm{C}$; $\mathrm{C}-10$, non-treated birch sap during storage at $10^{\circ} \mathrm{C} ; \mathrm{H}-10$, birch sap treated with $550 \mathrm{MPa}$ pressure for $120 \mathrm{sec}$ during storage at $10^{\circ} \mathrm{C}$.

${ }^{2)}$ Values are means $\pm \mathrm{SD}$ of triplicate determinations.

${ }^{33}$ Different superscripts within the each column (storage temperature groups) indicate significant differences $(\mathrm{p}<0.05)$.

식이 제어되어 대사물이 생성되지 않아 색도의 안정성을 기대할 수 있다고 판단된다. 전체적인 색도의 변화를 나타 내는 $\triangle \mathrm{E}$ 값 또한 $\mathrm{HPP}$ 처리한 수액의 변화폭이 적게 나타나 수액을 HPP 처리함으로 인해 색도의 안전정이 확보됨을 확인할 수 있었다.

\section{저장온도에 따른 수액의 미생물 변화}

자작나무 수액을 $5^{\circ} \mathrm{C}$ 에서 저장했을 때, control군과 HPP 처리군의 미생물 증식 변화는 Table 7과 같다. Control군은 초기 미생물 $1.54 \log \mathrm{CFU}$ 에서 7일, 13일에서 $3 \log \mathrm{CFU}$ 이상으로 기타음료의 규격에 적합하지 않았다. 반면, HPP 처리군은 저장 45 일까지 일반세균, 대장균군, 진균 등 모두 증식되지 않았고, 대장균 또한 음성으로 나타나 HPP처리로 일반세균 및 대장균군, 진균이 제어되어 미생물학적으로도 안전한 수준이라고 판단된다. $10^{\circ} \mathrm{C}$ 에서 저장한 처리군도 위와 동일하게 control군 초기 미생물 $1.54 \log \mathrm{CFU}$ 으로 나타났지만 4일후부터 $3 \log$ $\mathrm{CFU}$ 이상으로 규격을 초과하였다. 그러나, HPP처리군은 28 일간 저장하는 동안 일반세균, 대장균군, 진균은 모두 증식되지 않았고, 대장균 또한 음성으로 나타났다. Rajan 등(24)은 $10^{6} \mathrm{CFU}$ 의 Bacillus stearthermophilus 포자를 egg patties에 접종하여 가열조건 $\left(121^{\circ} \mathrm{C}, 15 \mathrm{~min}\right)$ 에서 $1.5 \mathrm{log}$ $\mathrm{CFU}$, 초고압과 가열 병행조건 $\left(700 \mathrm{Mpa}, 105^{\circ} \mathrm{C}, 5 \mathrm{~min}\right)$ 에서 $4 \log \mathrm{CFU}$ 감균되는 결과가 나타나고, deionized water에 접종한 경우 가열 초고압은 $6 \log \mathrm{CFU}$ 이상의 큰 감균 효과 가 있음을 알 수 있다. 이러한 연구결과는 고체보다 액체의 형태의 시료에 더 큰 효과를 보이는 것으로 판단된다. Table 3 에서 control군의 초기 일반세균이 약 $4 \log \mathrm{CFU}$, 대장균군 이 $1 \log \mathrm{CFU}$ 로 초기 살균방법인 여과, UV 살균으로도 충분히 제어하지 못하는 것을 확인할 수 있었고, HPP 처리 
후에는 초기 미생물을 제어하는 것으로 파악되었기 때문에 $\mathrm{HPP}$ 는 자작나무 수액의 안전성을 확보하고 그로 인해 저장 성을 증가시킬 수 있는 방법이라고 사료된다.

Table 7. Effect of HPP on microorganism in birch sap during storage at 5 and $10^{\circ} \mathrm{C}$

\begin{tabular}{|c|c|c|c|c|c|}
\hline & & & & & $\log \mathrm{CF}$ \\
\hline Sample ${ }^{1)}$ & $\begin{array}{c}\text { Storage } \\
\text { period (days) }\end{array}$ & $\begin{array}{c}\text { Total } \\
\text { bacteria }\end{array}$ & Coliform & E.coil & Fungi \\
\hline & 1 & $1.54 \pm 0.70^{2)}$ & $\mathrm{ND}$ & Negative & $0.60 \pm 0.30$ \\
\hline C-5 & 7 & $\mathrm{TNTC}^{3)}$ & TNTC & Negative & $0.48 \pm 0.00$ \\
\hline & 13 & TNTC & TNTC & Negative & $0.60 \pm 0.00$ \\
\hline & 1 & $\mathrm{ND}^{4)}$ & $\mathrm{ND}$ & Negative & $\mathrm{ND}$ \\
\hline & 7 & $\mathrm{ND}$ & $\mathrm{ND}$ & Negative & $\mathrm{ND}$ \\
\hline & 13 & $\mathrm{ND}$ & $\mathrm{ND}$ & Negative & $\mathrm{ND}$ \\
\hline & 18 & $\mathrm{ND}$ & $\mathrm{ND}$ & Negative & $\mathrm{ND}$ \\
\hline H-5 & 24 & $\mathrm{ND}$ & $\mathrm{ND}$ & Negative & $\mathrm{ND}$ \\
\hline & 30 & $\mathrm{ND}$ & $\mathrm{ND}$ & Negative & $\mathrm{ND}$ \\
\hline & 36 & $\mathrm{ND}$ & $\mathrm{ND}$ & Negative & $\mathrm{ND}$ \\
\hline & 42 & $\mathrm{ND}$ & $\mathrm{ND}$ & Negative & $\mathrm{ND}$ \\
\hline & 45 & $\mathrm{ND}$ & $\mathrm{ND}$ & Negative & $\mathrm{ND}$ \\
\hline & 1 & $1.54 \pm 1.18$ & $\mathrm{ND}$ & Negative & $0.65 \pm 0.18$ \\
\hline$C_{1}$ & 4 & TNTC & TNTC & Negative & $1.28 \pm 0.78$ \\
\hline$c-10$ & 8 & TNTC & TNTC & Negative & $\mathrm{ND}$ \\
\hline & 13 & TNTC & TNTC & Negative & $\mathrm{ND}$ \\
\hline & 1 & $\mathrm{ND}$ & $\mathrm{ND}$ & Negative & $\mathrm{ND}$ \\
\hline & 4 & $\mathrm{ND}$ & $\mathrm{ND}$ & Negative & $\mathrm{ND}$ \\
\hline & 8 & $\mathrm{ND}$ & $\mathrm{ND}$ & Negative & $\mathrm{ND}$ \\
\hline $\mathrm{H}-10$ & 13 & $\mathrm{ND}$ & $\mathrm{ND}$ & Negative & $\mathrm{ND}$ \\
\hline & 16 & $\mathrm{ND}$ & $\mathrm{ND}$ & Negative & $\mathrm{ND}$ \\
\hline & 21 & $\mathrm{ND}$ & $\mathrm{ND}$ & Negative & $\mathrm{ND}$ \\
\hline & 24 & $\mathrm{ND}$ & $\mathrm{ND}$ & Negative & $\mathrm{ND}$ \\
\hline
\end{tabular}

${ }^{1)} \mathrm{C}-5$, non-treated birch sap during storage at $5^{\circ} \mathrm{C} ; \mathrm{H}-5$, birch sap treated with 550 MPa pressure for $120 \mathrm{sec}$ during storage at $5^{\circ} \mathrm{C} ; \mathrm{C}-10$, non-treated birch sap during storage at $10^{\circ} \mathrm{C} ; \mathrm{H}-10$, birch sap treated with $550 \mathrm{MPa}$ pressure for 120 sec during storage at $10^{\circ} \mathrm{C}$.

${ }^{2)}$ All results are expressed as means for three replicates.

${ }^{3)} \mathrm{TNTC}$, Too numerous to count $\left(>1.0 \times 10^{3} \mathrm{CFU} / \mathrm{mL}\right)$.

${ }^{4} \mathrm{ND}$, Not detected.

\section{요 약}

초고압 공정(HPP)은 비가열 공정 중 하나로 식품 중의 세균 증식을 억제하는 방법으로 근래 들어 상업적으로 각광 받고 있다. 자작나무 수액은 여과 및 UV 살균과정을 거쳐 유통되지만 상업적으로 사용하기에는 식품공전 미생물 규 격에 적합하지 않아 추가 살균처리 없이 유통을 하기에는
적합하지 않은 단점이 있었다. 본 연구에서는 그 단점을 보완하고 저장유통기한을 연장하기 위해 비가열가공 살균 법으로 최근 주목받고 있는 $\mathrm{HPP}$ 를 적용하고자 하였다. 최 적 조건을 설정하기 위해 HPP 조건을 달리 하여 63 일 동안 저장하여 변화를 관찰하였고, 그 결과 압력이 높고 처리시 간이 길어질수록 미생물제어에 효과적이였다. 설정된 550 $\mathrm{MPa}, 120 \mathrm{sec}$ 의 조건으로 $\mathrm{HPP}$ 처리한 후 $5^{\circ} \mathrm{C}$ 와 $10^{\circ} \mathrm{C}$ 에 저장하며 미생물 및 품질변화를 관찰하였다. HPP 미처리군 의 경우에는 47일차에 급격한 미생물 증식 및 이화학 변화 가 일어났지만 $\mathrm{HPP}$ 처리군의 경우 $5^{\circ} \mathrm{C}$ 에서 $45^{\circ}$ 일, $10^{\circ} \mathrm{C}$ 에서 28 일간 저장하는 동안 일반세균, 대장균, 대장균군, 진균 모두 증식이 없어 미생물학적으로 안전한 것으로 나타났 다. 또한, $\mathrm{pH}$, 산도, 당도, 탁도 및 갈변도의 변화를 살펴본

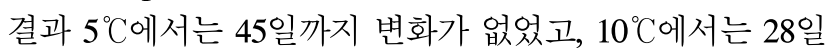
차에서 $\mathrm{pH}$ 감소, 산도, 갈변도, 탁도의 증가로 급격한 변화 로 24 일 저장하는 것이 이화학적으로도 안정하다고 평가하 였다. 이상의 결과로 볼 때 자작나무 수액은 효과적인 살균 처리를 하지 않으면 미생물증식, 탁도 및 갈변도 변화, 산도 증가로 유통기한이 4일 이하로 저장성이 많이 낮지만, HPP 처리함으로 인해 미생물 증식을 막고 그에 따른 수액의 이화학적 안정성을 확보하여 수액의 품질수명을 기존 미처 리군에 비해 6배 연장시킬 수 있을 것으로 판단된다.

\section{References}

1. Lee CH, Nho JW, Hwang IG, Shin CS, Lee JS, Jeong HS (2010) Shelf-life extension of Acer mono sap using ultra filtration. J Korean Soc Food Sci Nutr, 39, 455-460

2. Chung MJ, Lee SJ, Shin JH, Jo JS, Sung NJ (1995) The components of the sap from birches, bamboos and darae. J Korean Soc Food Nutr, 24, 727-733

3. Jeong SJ, Lee CH, Kim HY, Hwang IG, Shin CS, Park ES, Lee JS, Jeong HS (2011) Characteristics of Goroshoe (Acer mono Max.) sap with different collection times after ultra filtration. J Korean Soc Food Sci Nutr, 40, 753-758

4. Kim JH, Lee WJ, Cho YW, Kim KY (2009) Storage-life and palatability extension of Betula platyphylla sap using lactic acid bacteria fermentation. J Korean Soc Food Sci Nutr, 38, 787-794

5. Gansert D, Burgdorf M (2005) Effects of xylem sap flow on carbon dioxide efflux from stems of birch (Betula pendula Roth). Flora-Morphology, Distribution, Functional Ecology of Plants, 200, 444-455

6. Jeong SJ, Lee CH, Kim HY, Lee SH, Hwang IG, Shin CS, Lee JS, Jeong HS (2012) Quality characteristics of 
the white birch sap with varying collection periods. J Korean Soc Food Sci Nutr, 41, 143-148

7. Lee CH, Cho YM, Park ES, Shin CS, Lee JY, Jeong HS (2009) In vivo immune activity of sap of the white birch (Betula platyphylla var. japonica). Korean J Food Sci Technol, 41, 413-416

8. Harju L, Hulden S (1990) Birch sap as a tool for biogeochemical prospecting. J Geochem Explor, 37, 351-365

9. Choe SB, Han SJ, Han OH, Kim HS, Kang ST (2013) Effects of UV sterilization on quality of Acer mono sap. J Korean Soc Food Sci Nutr, 42, 148-152

10. Shin CS, Jeong HS, Lee CH (2011) Effects on shelf-life of betula platyphylla var. japonica sap using ultra filtration and UV sterilization system. Paper presented at Annual Meeting of The plant Resources Society of Korea, October 21, Jinan, Korea

11. Lee CH, Cho GS, Woo SY, Park ES (2006) Changes in antioxidant and immune activity of the research component of the storage conditions of birch sap. Paper presented at International symposium and annual meeting of The Korean Society of Food Science and Nutrition, October 18, Korea

12. Mok CK, Song KT, Lee SK, Park JH, Woo GJ, Lim SB (2000) Microbial changes of salted and fermented shrimp by high hydrostatic pressure treatment. Korean J Food Sci Technol, 32, 349-355

13. Ahn SI, Chung IA, Chung WS, Jhoo JW, Kim GY, Jeon JT (2016) Changes in lactic acid bacteria and physicochemical properties of yogurt made with high pressure processing treated milk. J Korean Soc Food Sci Nutr, 45, 889-893

14. Park SJ, Choi YB, Ko JR, Rha YA, Lee HY (2014) Quality characteristics of citrus fruit by cyclic low pressure drying and high hydrostatic pressure extraction. Korean Culinary Res, 20, 13-21
15. Sim JB (2016) Effect of combined high pressure processing and freezing technique on physicochemical properties of abalone (Haliotis discus hannai). MS Thesis, Konkuk University, Korea, p 1-5

16. Park WJ, Jwa MK, Hyun SH, Lim SB, Song DJ (2006) Microbial and quality changes during storage of raw oyster treated with high hydrostatic pressure. J Korean Soc Food Sci Nutr, 35, 1449-1455

17. Lee SH (2013) Advances in food preservation technology using high pressure. Food Science and Industry, 46, 42-48

18. KFDA (2016) Korea Food Code. Korea Food \& Drug Administration, Seoul, Korea, p 103-121

19. Kim CH, Kwon MC, Qadir SA, Hwang B, Nam JH, Lee HY (2007) Toxicity reduction and improvement of anticancer activities from Rhodiola sachalinensis A. Bor by ultra high pressure extracts process. Korean J Medicinal Crop Sci, 15, 411-416

20. Lim SB, Jwa MK, Mok CK, Park YS (2001) Quality changes in Kochujang treated with high hydrostatic pressure. Korean J Food Sci Technol, 33, 444-450

21. Chen D, Pang X, Zhao J, Gao L, Liao X, Wu J, Li $Q$ (2015) Comparing the effects of high hydrostatic pressure and high temperature short time on papaya beverage. Innovative Food Sci Emerging Technol, 32, $16-28$

22. Park HJ, Kim KY, Jeong HS (2009) Quality changes of jujube wine by hydrostatic pressure and freezing treatment during storage. J Korean Soc Food Sci Nutr, 38, 89-97

23. Oliveria ACM, Balaban MO (2006) Comparison of a colorimeter with a machine vision system in measuring color of gulf of mexico sturgeon fillets. Appl Eng Agric, 22, 583-587

24. Rajan S, Pandrangi S, Balasubramaniam VM, Yousef $\mathrm{AE}$ (2006) Inactivation of Bacillus stearothermophilus spores in egg patties by pressure-assisted thermal processing. LWT-Food Sci Technol, 39, 844-851 